\title{
BIRDS - NEW NAMES, NEW ORDER
}

BERNARD GOLLOP, Canadian Wildife Service, 115 Perimeter Road, Saskatoon, Saskatchewan. S7N OX4

Anyone who has seen the 1983 checklist of Saskatchewan birds will notice significant differences from the 1969 checklist, as well as from other lists, field guides and reference books in print prior to September $1983 .{ }^{69}$ The 1983 list incorporates the new names and new sequence of names proclaimed by the American Ornithologists' Union (AOU) in 1982. ${ }^{3}$ The AOU is an international association of (mostly) professional ornithologists. It is usually accepted as the finai authority on scientific and English names and the order in which these appear in such books as the Birds of Canada, The Birds of Alberta, Birder's Guide to Churchill, etc. This order is theoretically evolutionary, the oldest forms coming first, the most recently evolved last.

First, the new names: The following 41 name changes include those of most interest to anyone birding in the Prairie Provinces and Northwest Territories. Shown also is the confusion added by the use in the latest edition of Peterson's guide of some old, some new and some of Peterson's own names. ${ }^{8}$ (Table 1.)
The major reason for change is to come up with a uniform system of English names worldwide. ${ }^{7}$ To date the same species has been known by different English names in different countries and the same English name has referred to different species in various countries. The addition of adjectives such as "American" separates, for instance, "our" Black Duck from the Black Duck of Africa.'

These changes are in addition to those promulgated by the same organization some 10 years ago which resulted in one species name encompassing what had once been considered separate species but had since been found to be only subspecies, e.g., Common Flicker and Yellow-rumped Warbler. ${ }^{2}$ Included was Darkeyed Junco for the Slate-colored and Oregon Juncos. Unfortunately, Peterson has seen fit to substitute Northern for Darkeyed. ${ }^{8}$ On the other hand, the AOU has now changed Common Flicker to Northern Flicker. The July 1982 AOU list retained Common Raven but a more recent paper states that the new name is now Northern Raven. ${ }^{5}$ However the published volume stays

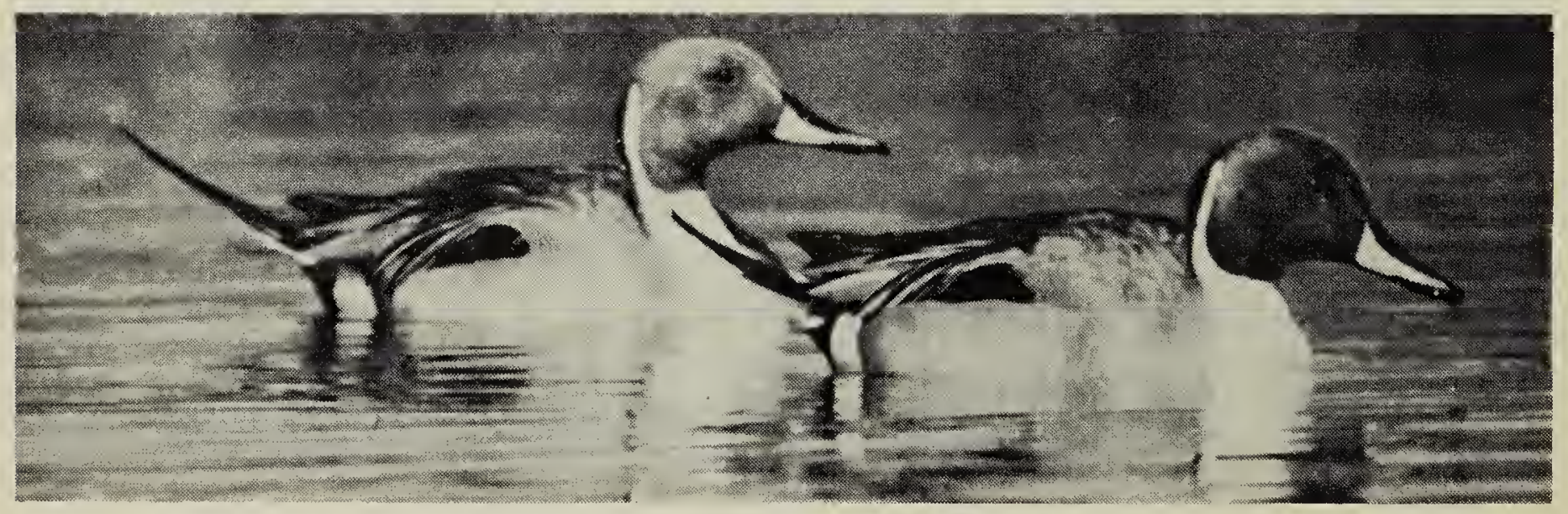


Table 1. AOU NAME CHANGES AND PETERSON'S FIELD GUIDE NAMES

\begin{tabular}{|c|c|c|c|}
\hline Previous AOU & Peterson 1980 & & NeW AOU \\
\hline White Pelican & $P^{*}$ & & American White Pelican \\
\hline Louisiana Heron & $P$ & & Tricolored Heron \\
\hline Green Heron & P & & Green-backed Heron \\
\hline Black-crowned Night Heron & $P$ & & Black-crowned Night-Heron \\
\hline Yellow-crowned Night Heron & $P$ & & Yellow-crowned Night-Heron \\
\hline Whistling Swan & $P$ & & Tundra Swan \\
\hline White-fronted Goose & $P$ & & Greater White-fronted Goose \\
\hline American Green-winged Teal & & $P$ & Green-winged Teal \\
\hline Black Duck & & $P$ & American Black Duck \\
\hline Pintail & Common Pintail & & Northern Pintail \\
\hline European Wigeon & & $P$ & Eurasian Wigeon \\
\hline Goshawk & & $P$ & Northern Goshawk \\
\hline Marsh Hawk & $P$ & $P$ & Northern Harrier \\
\hline Greater Prairie Chicken & $P$ & & Greater Prairie-Chicken \\
\hline Turkey & & $P$ & Wild Turkey \\
\hline Common Gallinule & $P$ & & Common Moorhen \\
\hline American Golden Plover & Lesser Golden Plover & & Lesser Golden-Plover \\
\hline Northern Phalarope & & & Red-necked Phalarope \\
\hline Black-headed Gull & $P$ & & Common Black-headed Gull \\
\hline Barn Owl & $P$ & & Common Barn Owl \\
\hline Screech Owl & Common Screech Ow & & Western Screech-Owl \\
\hline Hawk Owl & & & Northern Hawk-Owl \\
\hline Pygmy Owl & (Not included) & & Northern Pygmy-Owl \\
\hline Saw-whet Owl & $\mathrm{P}$ & & Northern Saw-whet Owl \\
\hline Poor-will & $P$ & & Common Poorwill \\
\hline $\begin{array}{l}\text { Northern Three-toed } \\
\text { Woodpecker }\end{array}$ & $P$ & & Three-toed Woodpecker \\
\hline $\begin{array}{l}\text { Black-backed Three-toed } \\
\text { Woodpecker }\end{array}$ & $P$ & & Black-backed Woodpecker \\
\hline Common Flicker & $P$ & & Northern Flicker \\
\hline Eastern Wood Pewee & Eastern Pewee & & Eastern Wood-Pewee \\
\hline Western Wood Pewee & (Not included) & & Western Wood-Pewee \\
\hline Rough-winged Swallow & $\mathrm{P}$ & & $\begin{array}{l}\text { Northern Rough-winged } \\
\text { Swallow }\end{array}$ \\
\hline Common Crow & $P$ & $P$ & American Crow \\
\hline Long-billed Marsh Wren & $P$ & $P$ & Marsh Wren \\
\hline Short-billed Marsh Wren & $P$ & $P$ & Sedge Wren \\
\hline Dipper & (Not included) & & American Dipper \\
\hline Wheatear & & $P$ & Northern Wheatear \\
\hline Mockingbird & & $P$ & Northern Mockingbird \\
\hline Starling & & $P$ & European Starling \\
\hline Cardinal & & $P$ & Northern Cardinal \\
\hline Gray-crowned Rosy Finch & (Not included) & & Rosy Finch \\
\hline Tree Sparrow & & $P$ & American Tree Sparrow \\
\hline
\end{tabular}

* $P$ to the left indicates that Peterson uses old name; $P$ to the right that he uses new name. 
with Common Raven (Scott Wood, Carnegie Museum, pers. comm.)

The two most ridiculous changes are the new Three-toed Woodpecker and Marsh Wren. Because the old names will linger on, if someone now announces that she saw a marsh wren, her audience cannot be sure whether it was a Sedge or a Marsh Wren. And if three-toed woodpecker appears in a publication that does not capitalize bird names, the species referred to will remain uncertain in perpetuity. Also the red-necked phalarope, if not capitalized, could refer to Wilson's Phalarope or Red Phalarope.

Now, about the new order: The sequence of families remains the same from loons through upland game birds, although here and later in the list some families have been combined and others divided. (Saskatchewan's 52 families in 1969 have become 44.) Cranes now follow rails and coots, and avocets are inserted between plovers and the rest of our shorebirds. Dipper follows wrens, while kinglets and thrushes (now the same family) precede thrashers. Near the end is the largest family, formerly most of four families, followed by a family that includes Pine and Evening Grosbeaks (but not Rose-breasted or Black-headed), redpolls, goldfinches and crossbills. The last species in the new order? The House Sparrow in its own family.

And, if the reordering of families is not frustrating enough, it appears that most species within most families have been shifted around so that birdwatchers will spend more time looking for a species in the checklist than in its habitat. Just a few examples from the largest family: Black-and-white is no longer first on our warbler list; it is buried about 2/3 of the way through warblers. And don't look for the redstart to be the last warbler any more. You will also find that the blackbirdmeadowlark tribe follows sparrows, longspurs and Snow Bunting. Ornery, inexplicable and unjustifiable as such change's may seem, they are usually based on new information on species relationships determined from anatomical, biochemical and behavioral studies conducted since the previous checklist of $1957 .{ }^{4} 1$

Anyone wishing a list of Prairie Province birds with their official English names and new order can obtain one by writing the author.

\section{Good bird-naming!}

1 AMERICAN ORNITHOLOGISTS' UNION. 1957. Check-list of North American birds. Port City Press, Baltimore.

2 AMERICAN ORNITHOLOGISTS' UNION. 1973. Thirty-second supplement to the American Ornithologists' Union checklist of North American birds. Auk 90:411-419.

3 AMERICAN ORNITHOLOGISTS' UNION. 1982. Thirty-fourth supplement to the American Ornithologists' Union checklist of North American birds. Auk 99(3): Supplement.

4 DEBENEDICTUS, PAUL. 1982. Gleanings from the technical literature. Birding 14:192-194, 216-218.

5 DEBENEDICTUS, P. A. 1983. Coming! A new official checklist of North American birds - A revolution in Avian nomenclature. American Birds 37:3-8.

6 KREBA, ROBERT. 1983. Field checklist of Saskatchewan birds. Museum of $\mathrm{Na}$ tural History, Regina.

7 PARKES, K.C. 1983. The more things change ... Living Bird Quarterly 2(3): 14-17.

8 PETERSON, R. T. 1980. A field guide to the birds east of the Rockies. Houghton Mifflin, Boston.

9 SASKATCHEWAN MUSEUM OF NATURAL HISTORY. 1969. Field check-list of Saskatchewan birds. Sask. Dept. of Culture and Youth, Regina. 